\title{
Effect of different levels of buds load on bud behavior and fruit quality of Early Sweet grapevine
}

\author{
Thoraua S. A. Abo-ELwafa \\ Viticulture. Dept. Hort. Res. Institute. Agric. Res. Center, Giza, Egypt \\ Corresponding author: thorayaaboelwafa@yahoo.com
}

\begin{abstract}
This investigation was carried outduring both 2016\& 2017 seasons in a private vineyard at El-Khatatba region, Minufyia Governorate to studytheEffect of different levels of buds load on bud behavior and the quality of Early Sweet grapes. The chosen vines were 7-yearold, grown in a sandy soil, spaced at 2 X 3 meters ,irrigated by the drip irrigation system, trellised by the Spanish Parron shape system. Vines were trained to quadrilateral cordon and spur- pruned. Vines pruned to three different levels of bud load (48,72 and 96 buds/vine) and number of buds per fruiting spurs adopted to 2,4and 6 buds/spur.The results showed that (48bud/vine) 24 spurs $\times 2$ budsincreased bud behavior,physical characteristics, vegetative growth, wood ripening and weight of pruning.In addition,total carbohydrates in canes, however, the levelload of (96 bud/vine) 24 spurs $\times 4$ budsgave the highest yield per vinein both seasons. Finlay, the best results was (48 bud/vine) namely 24,12 and 8 fruiting spurs adopted to 2,4and 6 buds/spur,respectively.
\end{abstract}

Keywords: Grapevines, Early Sweet, spur pruned, vegetative growth, yield and quality

\section{Introduction}

Grape is considering one of the most important fruit crops all over the world and popular and favorite fruit crops. Moreover, it is considered to be the second most important fruit crop after citrus in Egypt as its acreage, production and exportation in Egypt.

The production of grapes in Egypt increased as a new varieties became known and culture practices post-harvest handling as well as a new marketing methods utilized in the new reclaimed areas in the Egyptian deserts particularly the early ripening cultivars such as "Flame seedless", "Superior" and "Early Sweet

Early sweet grapevine cv. is considered a prime and outstanding grapevine cv. grown under Egypt conditions. It ripens early especially when treated with breakages and easily marketing to most foreign countries. Early Sweet Grapes is a large seedless berry with a creamy white color. The high sugar level gives this grape a sweet flavor with a hint of Muscat and an extremely high juice level.

Pruning is the most important cultural practice in the management of grapevine to sustain production and productivity. Pruning methods have been developed to balance fruit productivity, vegetative growth and attain maximum yield without reducing vine vigour. An increase in the severity of pruning will increase the vigor of individual shoot at the expense oftotal growth and crop (Weaver, 1976 and Celiket al., 1998). Pruning practice through which grape production can be increased and cluster quality improved.

Bud load is the most important factor affecting yield and cluster quality as well as vine vigor of Thompson seedless grapevines Morris and Cawthon (1980); Fawzi et at., 1984 ; Marwad et. al., (1993); Omar and Abdel-kawi, 2000; Rubio et al.,(2002) on
Tempranillo variety Khamis et al., (2017)on superior grapevines. Adjusting the length of fruiting spur is necessary to balance growth and fruiting status/vine nutritional status and bud fertility (Tamura et al., 2002 and Ranspise et al., 2003).Previous studies showed that adjusting the length of fruiting spurs in most grapevine cvs. is considered the main reasons for promoting productivity (Abdel -Fattah et al., 1993; Kamel, 2002; Ansam, 2002; Awad, 2003; Nejatian, 2003; Jarad, 2004 ; Abdel-Mohsen, 2013; Ali and MoumenKh. Mohamed, 2016) and Khamis et al (2017)

Therefore the objective of this study is to determine the optimum bud load for Early sweet grapevine and their effect on bud behavior, fruit quality, yield and vegetative growth.

\section{Materials and Methods}

This study was carried out during two consecutive 2016\&2017 experimental seasons in a private vineyard at El-Khatatba, Menoufiya governorate, Egypt on Early sweet grapevines cultivar. The vines were 7year-old, grown in a sandy soil, spaced at 2 X 3 meters apart, irrigated by the drip irrigation system, trellised by the Spanish Parron shape system.

Vines were trained to quadrilateral cordon and spur- pruned. The experiment consisted of nine treatments arranged in a randomized complete block design, a hundred and eight uniform vines were chosen. Each twelve vines acted as a replicate and each three replicates acted as treatment. The vines were pruned during at the last weekof December during two seasons of study.All vines received the same cultural managements recommended by ministry agriculture. 
The study included the following treatments T1-pruning at 24 fruiting spurs $\times 2$ buds $=48$ buds T2-pruning at 12 fruiting spurs $\times 4$ buds $=48$ buds T3-pruning at 8 fruiting spurs $\times 6$ buds $=48$ buds T4-pruning at 36 fruiting spurs $\times 2$ buds $=72$ buds T5-pruning at 18 fruiting spurs $\times 4$ buds $=72$ buds T6-pruning at 12 fruiting spurs $\times 6$ buds $=72$ buds T7-pruning at 48 fruiting spurs $\times 2$ buds $=96$ buds T8-pruning at 24 fruiting spurs $\times 4$ buds $=96$ buds T9-pruning at 16 fruiting spurs $\times 6$ buds $=96$ buds

\section{1-Bud behavior}

During the two seasons, the following measurements were recorded:

\section{a-Bud burst:}

\section{b- Percentage of bud burst:}

Number of buds were counted one month after bud burst and the percentage of bud burst were calculated as follows according to Bessis(1960).

Bud burst $\%=\frac{\text { No of bursted buds per vine }}{\text { Total buds per vine }} \times 100$

c-Bud fertility:

Number of clusters per vine were counted and divided by the total number of buds and the fertility was calculated as follows according to Bessis(1960).

Bud fertility $\%=\quad \frac{\text { No of clusters per vine }}{\text { no of Total buds left at winter pruning }}$
$\times 100$

2-Morphological and vegetative growth

Vegetative growth parameters were determined after two weeks of fruit set as follows:

\section{1- Average shoots length $(\mathrm{cm})$.}

Twenty vegetative shoot were measured as average $(\mathrm{cm})$, also number leaves fail date were calculated for each treatment when the leaves began take the red color and begins fail ( El-Ashram 1993).

\section{2- Average leaf area $\left(\mathrm{cm}^{2}\right)$}

Twenty leaves / vine were picked at Veraison of the apical $6^{\text {th }}$ and $7^{\text {th }}$ leaves using a CI-203- Laser Areameter made by CID, Inc., Vancouver, USA.

3-N, $\mathbf{P}, \mathbf{K}$ and Mgcontent in the leaves:

At full bloom, samples of 20 leaf petioles per each replicate were taken from

leaves opposite to cluster were used for the determination of N, P and $\mathrm{K}$ according to (Cottenieet al.1982).

4- Chlorophyll content in theleaves:Sixth and seventh leaves from the tip of the growing shoots were used for the determination of total chlorophyll content in the leaves after two weeks from last treatment according to (Mackinny, 1941)

3-Yield and physical characteristics of clusters

Harvesting indices (TSS\% and acidity \%) were weekly monitored from version till maturity when TSS reached about 16-17\% according to Tourk et al.,(1995). a- Average cluster length (cm).

b- Average cluster width $(\mathrm{cm})$.

c- Average cluster weight (g).

$\mathrm{d}$ - Yield /vine =number of clusters/vine $\times$ average cluster weight.

4-physical characteristics of berries

a- Average berry weight ( $\mathrm{g}$ ).

b- Total number of berries per cluster

c- Average size of berries $(\mathrm{cm})^{3}$

d- Average berry width $(\mathrm{cm})$

e- Average berry length $(\mathrm{cm})$

f- Shot berries per cluster $\%=$ Number of shot berries per cluster $\times 100$

Total number of

berries per cluster

\section{3- Chemical characteristics of berries}

a- Total soluble solids (TSS \% in berry juice using a hand refract meter.

b- Total treatable acidity (as tartaric acid \%) according to the Official Analysis Methods (A.O.A.C., 2000).

c- TSS / acid ratio.

\section{At dormant seasons:}

a- Wood ripening :

b-Weight of pruning: was carried out at the time of winter pruning $(\mathrm{g})$

c-Total carbohydrates in cane content (\%):from fruitingcanes for next seasonwere determined calorimetrically by using reagent according to the method described by Herbert et al.,( 1971)

\section{Statistical analysis :}

All the obtained data during ecal season of this study were subjected to statistical of various according to the method described by (Snedecor and Cochran,1990). However, the differences means were differentiated by using Duncan's multiple rage test (Duncan,1955).

\section{Result and Discussion}

\section{1-Bud behavior}

a-Time of bud burst:

Data presented in table (1) showed that pruning Early sweet grapevines atlevel 24 spurs $\times 2$ buds $(48$ buds/vine) advanced the beginning of bud burst date compared with other treatments followed by the vines were pruned at 36 spurs $\times 2$ buds (72buds/vine)and finally the vineswere pruning at level1 6 spurs $\times 6$ buds (96 buds/vine) in both seasons of study.

\section{b-Percentage of bud burst and bud fertility:}

From table (1) it is clear that the bud burst and bud fertility percentage was increased significantly by decreasing the number of bud load/ vine in the two seasons. Since, the highest bud burst and bud fertility 
percentage was associated with the lowest bud load (48 buds/vine) buds compared with (72 buds/vine) and (96 buds/vine) respectively in both seasons of study. Treatments under each levels (48, 72 or 96 buds) were nonsignificantly between them in both seasons. Moreover, vines werepruned at 8 spurs with 6 buds gave the highest bud burst and bud fertility percentage followed by the vines were pruned at 12 spurs $\times 4$ buds compared with the other treatments while vines were pruned at 24 spurs with 4 buds gave the lowest bud burst and bud fertility percentage compared with the other treatments during both seasons under the study.

The results obtained also by Ali and Moumen Mohamed, 2016, Omar and Abd EL-Kawi (2000) found that increasing bud load reduces bud fertility\%. Furthermore, leaving 18 canes with 4 nodes andleaving 21 canes with 3 nodes give a highest significant value of bud fertility percentage in the first and second seasons respectively while the lowest value was obtained when leaving 8 cane with 6 nodes in both season of the study.

Table 1. Effect of different buds load levels on bud behavior of Early Sweet grapevines in 2016 and 2017 seasons

\begin{tabular}{|c|c|c|c|c|c|c|c|}
\hline \multicolumn{2}{|c|}{ Treatments } & \multicolumn{2}{|c|}{ Bud burst date } & \multicolumn{2}{|c|}{ Bud burst \% } & \multicolumn{2}{|c|}{ Bud fertility \% } \\
\hline & & 2016 & 2017 & 2016 & 2017 & 2016 & 2017 \\
\hline \multirow{3}{*}{48} & 24 spurs $\times 2$ buds & $13 / 2$ & $12 / 2$ & $96.2 \mathrm{a}$ & $97.5 \mathrm{a}$ & $78.3 \mathrm{a}$ & $81.2 \mathrm{~b}$ \\
\hline & 12 spurs $\times 4$ buds & $15 / 2$ & $14 / 2$ & $96.9 a$ & $98.45 \mathrm{a}$ & $82.8 \mathrm{a}$ & $89.6 \mathrm{a}$ \\
\hline & 8 spurs $\times 6$ buds & $15 / 2$ & $14 / 2$ & $96.9 \mathrm{a}$ & $98.5 \mathrm{a}$ & $82.3 \mathrm{a}$ & $91.2 \mathrm{a}$ \\
\hline \multirow{3}{*}{72} & 36 spurs $\times 2$ buds & $14 / 2$ & $15 / 2$ & $91.3 \mathrm{ab}$ & $93.2 \mathrm{ab}$ & $57.4 \mathrm{~b}$ & $57.9 \mathrm{c}$ \\
\hline & 18 spurs $\times 4$ buds & $16 / 2$ & $17 / 2$ & $90.1 \mathrm{ab}$ & $91.8 \mathrm{ab}$ & $56.9 \mathrm{~b}$ & $57.3 \mathrm{c}$ \\
\hline & 12 spurs $\times 6$ buds & $17 / 2$ & $15 / 2$ & $89.9 \mathrm{ab}$ & $91.7 \mathrm{ab}$ & $54.2 \mathrm{~b}$ & $58.0 \mathrm{c}$ \\
\hline \multirow{3}{*}{96} & 48 spurs $\times 2$ buds & $17 / 2$ & $16 / 2$ & $87.5 \mathrm{ab}$ & $90.0 \mathrm{~b}$ & $40.9 \mathrm{c}$ & $41.9 \mathrm{~d}$ \\
\hline & 24 spurs $\times 4$ buds & $18 / 2$ & $18 / 2$ & $84.0 \mathrm{~b}$ & $87.45 b$ & $38.0 \mathrm{c}$ & $47.2 \mathrm{~d}$ \\
\hline & 16 spurs $\times 6$ buds & $20 / 2$ & $19 / 2$ & $87.5 \mathrm{ab}$ & $89.6 \mathrm{~b}$ & $47.9 \mathrm{~b}$ & $41.9 \mathrm{~d}$ \\
\hline
\end{tabular}

Values within each column followed by the same letter/s are not significantly different at 5\% level

\section{2- Vegetative growth \\ a- Shoot length and Leaf area}

With respect to the effect of buds load on shoot length and leaf area data obtained in Table (2) show that 2 buds/spur treatments was the superior treatment in this respect as it enhanced shoot length and leaf area inEarly sweet grapevines as compared with 4 and 6 buds/spur treatments in this concern during 2016 and 2017 seasons.

The vine were pruning at 24 spurs/2 buds (48 buds/vine) and 48 spurs/2 buds (96 buds/vine) gave the highest value compared with the other treatments during both seasons under the study, However The vine were pruning at 12 spurs/8 buds (96 buds/vine) recorded the lowest shoot length and leaf area in both seasons.

This increased with sever pruning may be due to the strong reduction in pruned wood as compared to light pruning, thus affects that balance between nitrogen and carbohydrates in favorite of nitrogen which promotes vegetative growth. The findings of Abd El-Baki (2003) showed that there was a gradual increase in shoot length of both "King Ruby" and "Thompson seedless" all along the growing seasons. However, "King Ruby" vines produced the longest shoots under the level of 12 buds/vine followed by 18 and 24 buds/vine, while the shortest ones were noticed in case of 30 buds/vine. In addition, Ali and MoumenKh. Mohamed, (2016) found that thehighest shoot length and leaf area were recorded on the vines that pruned to leave 15 fruiting spurs x 4eyes. Also,
Sabbatiniet al. (2015) mentioned that as number of nodes retained increased, vine size and leaf area.

\section{b- chlorophyll A and B}

Regarding chlorophyll A and B data in Table (2) revealed that pruning Early sweet grapevinesat level 24 spurs $\times 2$ buds (48 buds/vine) increased chlorophyll $A$ and $B$ followed by the vines were pruned at 12 spurs $\times 4$ buds(48 buds/vine) as compared with the other treatments in 2016 and 2017seasons, respectively. While, vines pruned at 48 spurs with 2 buds (96 buds/vine) gave the lowest chlorophyll A and B compared with the other treatments in both seasons of study.

These results are in contrast with those reported by Velu (2001)and Senthilkumar et al (2015) observed that the maximum chlorophyll content $(2.699 \mathrm{mg} / \mathrm{g})$ was registered at a pruning level of $67 \%$ of canes to 5 bud level and $33 \%$ of the canes to 2 bud level. In addition, Ali, et al.,(2016) found that the highest chlorophyll A and B were recorded on the vines that pruned to leave 8 canes $x 10$ eyes 
Table 2.Effect of different of buds load levels on Shoot length, Leaf area chlorophyll A and B of Early Sweet grapevines in 2016 and 2017 seasons

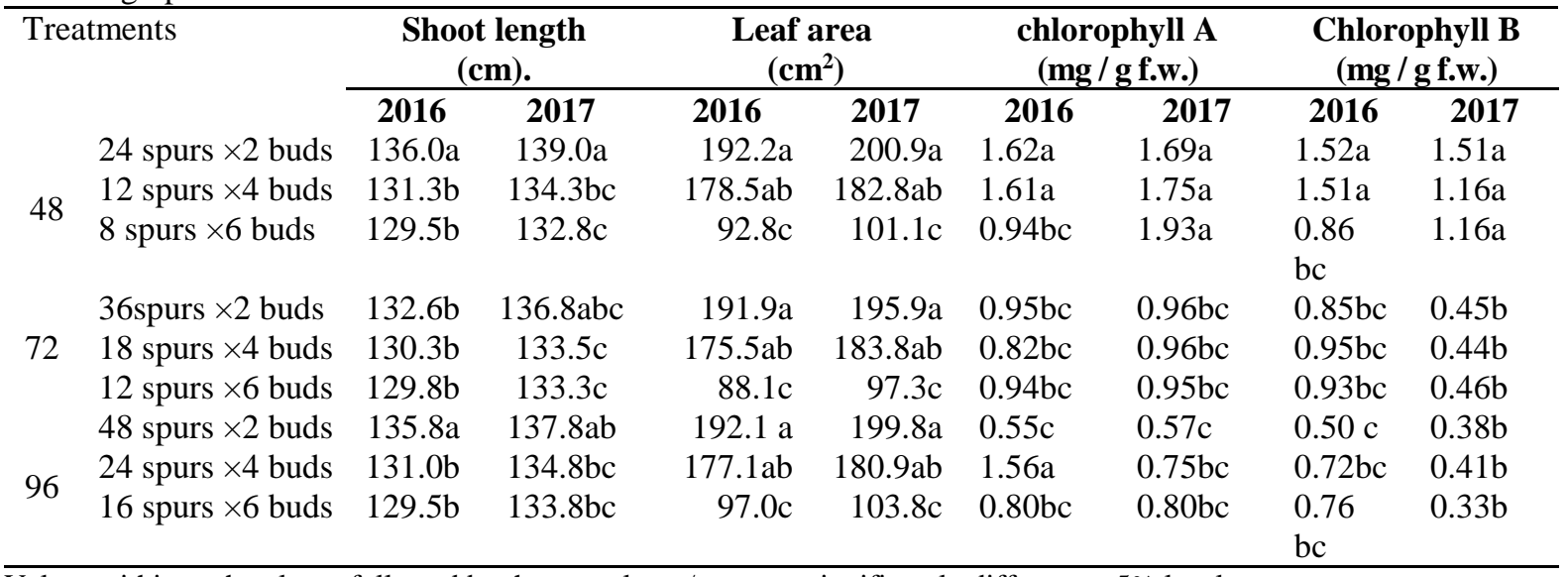

Values within each column followed by the same letter/s are not significantly different at 5\% level

\section{$\mathrm{N}, \mathrm{P}, \mathrm{K}$ and $\mathrm{Mg}$ content in the leaves}

The data presented in Table 3 revealed that vineswereprunedat 24 spurs/2 buds( 48 buds/vine) gave the highest percentage of phosphorous,potassium andmagnesium comparedwith (72 buds/vine)and (96 buds/vine) respectively in both seasons of studyfollowedby the vines were pruned 12 spurs $\times 4$ buds as compared with the other treatments in 2016 and 2017seasons, respectively. On the other hand ,the lowest value percentage of phosphorous ,potassium andmagnesium was obtained when the vine were pruning at 48 spurs $\times 2$ buds( 96 buds/vine)in both seasons of the study whiledifferent levels of buds load gave a non significantly differences in percentage of nitrogen compared of them under this study.
These results as a general trend are in agreement with(Weaver, 1976) The increase on the leaf chemical constituents at the higher levels of vine load might be attributed to the promotion on the leaf area which resulted in enhancing photosynthesis process as well as the reduction on main shoot length and number of leaves which aids in reducing the depletions of these nutrients. Ali, (2016)showed that the maximum values of chlorophylls ( $\&$ \& b), total chlorophylls, N,P, K and $\mathrm{Mg}$ in the leaves were recorded on the vines pruned to leave 102 eyes/vine and sprayed three times with citric acid at $0.4 \%$. These findings were true during both seasons.

Table 3. Effect of different levels of buds load on N, P, K and Mg of Early Sweet grapevines in 2016 and 2017 seasons

\begin{tabular}{|c|c|c|c|c|c|c|c|c|c|}
\hline \multirow{2}{*}{\multicolumn{2}{|c|}{ Treatments }} & \multicolumn{2}{|c|}{$\mathbf{N} \%$} & \multicolumn{2}{|c|}{$\mathbf{P} \%$} & \multicolumn{2}{|c|}{$\mathbf{K} \%$} & \multicolumn{2}{|c|}{ Mg \% } \\
\hline & & 2016 & 2017 & 2016 & 2017 & 2016 & 2017 & 2016 & 2017 \\
\hline & 24 spurs $\times 2$ buds & $1.88 \mathrm{a}$ & $1.58 \mathrm{a}$ & $0.36 a$ & $0.39 a$ & $0.86 \mathrm{a}$ & $0.89 a$ & $0.49 a$ & $0.50 \mathrm{a}$ \\
\hline \multirow[t]{3}{*}{48} & 12 spurs $\times 4$ buds & $1.61 \mathrm{a}$ & $1.53 \mathrm{a}$ & $0.36 \mathrm{a}$ & $0.38 \mathrm{a}$ & $0.95 \mathrm{a}$ & $0.95 \mathrm{a}$ & $0.49 \mathrm{a}$ & $0.49 \mathrm{a}$ \\
\hline & 8 spurs $\times 6$ buds & $1.43 \mathrm{a}$ & $1.73 a$ & $0.36 \mathrm{a}$ & $0.37 \mathrm{a}$ & $0.84 \mathrm{a}$ & $0.85 \mathrm{a}$ & $0.48 \mathrm{a}$ & $0.48 \mathrm{a}$ \\
\hline & 36 spurs $\times 2$ buds & $1.46 \mathrm{a}$ & $1.54 \mathrm{a}$ & $0.31 \mathrm{a}$ & $0.34 \mathrm{a}$ & $0.64 b c$ & $0.66 b c$ & $0.36 \mathrm{~b}$ & $0.36 b$ \\
\hline \multirow[t]{3}{*}{72} & 18 spurs $\times 4$ buds & $1.56 \mathrm{a}$ & $1.26 \mathrm{a}$ & $0.29 \mathrm{a}$ & $0.35 \mathrm{a}$ & $0.69 b$ & $0.70 b$ & $0.34 b$ & $0.35 \mathrm{~b}$ \\
\hline & 12 spurs $\times 6$ buds & $1.39 \mathrm{a}$ & $1.75 \mathrm{a}$ & $0.30 \mathrm{a}$ & $0.32 \mathrm{a}$ & $0.57 \mathrm{~cd}$ & $0.58 \mathrm{~cd}$ & $0.33 b$ & $0.33 b$ \\
\hline & 48 spurs $\times 2$ buds & $1.69 \mathrm{a}$ & $1.36 \mathrm{a}$ & $0.18 b$ & $0.20 \mathrm{~b}$ & $0.51 \mathrm{~d}$ & $0.53 \mathrm{~d}$ & $0.31 b$ & $0.31 b$ \\
\hline \multirow[t]{2}{*}{96} & 24 spurs $\times 4$ buds & $1.64 \mathrm{a}$ & $1.61 \mathrm{a}$ & $0.19 b$ & $0.21 b$ & $0.51 \mathrm{~d}$ & $0.53 d$ & $0.31 b$ & $0.32 \mathrm{~b}$ \\
\hline & 18 spurs $\times 6$ buds & $1.45 \mathrm{a}$ & $1.57 \mathrm{a}$ & $0.19 b$ & $0.21 b$ & $0.50 \mathrm{~d}$ & $0.31 \mathrm{~b}$ & $0.31 \mathrm{~b}$ & $0.32 b$ \\
\hline
\end{tabular}

Values within each column followed by the same letter/s are not significantly different at 5\% level

\section{3-Yield and physical characteristics of clusters}

\section{a- Cluster length and width}

Data in Table (4) declared that the buds load of ( 48 buds/vine) 24 spurs/2 buds produced the highest significant cluster length and width compared with pruning (72 buds/vine) and (96 buds/vine) in both seasons. However the treatment of (96 buds/vine) 24 spurs/4 buds recorded the lowest cluster length and widthin both 2016 and 2017 seasons

b- Cluster weight and Yield /vine data in Table (5) revealed that pruningEarly sweet grapevinesat(48 buds/vine) 24 spurs $/ 2$ buds produced the highest cluster weight compared with pruning at(72 buds/vine)and (96 buds/vine) in both seasons. While, pruning at(72 buds/vine) 12 spurs/ 6 buds recorded the lowestcluster weight in both 2016 and 2017 seasons. Regardingyield per vine pruned (96 buds/vine) 24 spurs/4 buds produced the highest yield per vine compared with leaving (72 buds/vine) and (48 buds/vine) in both seasons. On the other hand,pruning 
at (48buds) 24 spurs/2 buds recorded the lowestyield per vine in both 2016 and 2017 seasons.

These results agreed with those findings of Ansam(2002)and EL-Bazet al., (2002) On Kings Ruby grapevine vines pruned to 40 or 60 buds/vine produced the highest width and length of clusters compared with the other bud load (20, 50 and 80bud/vine) Aly (2001).Fawziet al. (2015) showed that interaction between the two studied factors was insignificant in most cases. The highest value of cluster width and cluster length was noticed with the pruned vine at 2 eyes per cane plus 24 buds.

Table 4. Effect of different of buds loadlevels on Cluster length $(\mathrm{cm})$, width $(\mathrm{cm})$, Cluster weight $(\mathrm{g})$ and Yield /vine (kg) of Early Sweet grapevines in 2016 and 2017 seasons

\begin{tabular}{|c|c|c|c|c|c|c|c|c|c|}
\hline \multirow{2}{*}{\multicolumn{2}{|c|}{ Treatments }} & \multicolumn{2}{|c|}{$\begin{array}{c}\text { Cluster length } \\
(\mathrm{cm})\end{array}$} & \multicolumn{2}{|c|}{$\begin{array}{c}\text { Cluster width } \\
\text { (cm) }\end{array}$} & \multicolumn{2}{|c|}{$\begin{array}{c}\text { Cluster weight } \\
\text { (g) }\end{array}$} & \multicolumn{2}{|c|}{$\begin{array}{c}\text { Yield /vine } \\
\text { (kg) }\end{array}$} \\
\hline & & 2016 & 2017 & 2016 & 2017 & 2016 & 2017 & 2016 & 2017 \\
\hline \multirow{3}{*}{48} & 24 spurs $\times 2$ buds & $28.3 \mathrm{a}$ & $29 a$ & $24.2 \mathrm{a}$ & $25.8 \mathrm{a}$ & $512.5 \mathrm{a}$ & 525 a & $15.75 \mathrm{~d}$ & $\begin{array}{l}17.55 \\
c\end{array}$ \\
\hline & 12 spurs $\times 4$ buds & $27.5 \mathrm{a}$ & $29 \mathrm{a}$ & $24.8 \mathrm{a}$ & $23.8 \mathrm{ab}$ & $412.5 \mathrm{bcd}$ & $445 \mathrm{bc}$ & $17.01 \mathrm{bcd}$ & $18.91 \mathrm{abc}$ \\
\hline & 8 spurs $\times 6$ buds & $27.4 \mathrm{a}$ & $28 . \mathrm{a}$ & $16.5 \mathrm{de}$ & $15.3 \mathrm{e}$ & $385 \quad \mathrm{~d}$ & $410 \mathrm{~cd}$ & $17.35 \mathrm{bcd}$ & $19.03 \mathrm{abc}$ \\
\hline \multirow{3}{*}{72} & 36 spurs $\times 2$ buds & $24 \quad \mathrm{~b}$ & $26 a b$ & $22 \mathrm{ab}$ & $22.3 a b c$ & 400 & $437.5 \mathrm{bc}$ & $18 \mathrm{bc}$ & $20.23 \mathrm{ab}$ \\
\hline & 18 spurs $\times 4$ buds & $23.5 \mathrm{~b}$ & $24.5 b$ & $19.5 \mathrm{bcd}$ & $20.3 \mathrm{bd}$ & $387.5 \mathrm{~d}$ & $387.5 \mathrm{~cd}$ & $19.01 \mathrm{ab}$ & $19.5 \mathrm{abc}$ \\
\hline & 12 spurs $\times 6$ buds & $27.8 \mathrm{a}$ & $27.3 \mathrm{~b}$ & $19.8 \mathrm{bcd}$ & $18.8 \mathrm{cde}$ & 375 & $367.5 \mathrm{~d}$ & $16.35 \mathrm{~cd}$ & $18.45 \mathrm{bc}$ \\
\hline \multirow{3}{*}{96} & 48 spurs $\times 2$ buds & $23.8 \mathrm{~b}$ & $24.5 b$ & $20.5 b c$ & 19.8bce & 460 abc & $497.5 \mathrm{ab}$ & $18.37 \mathrm{abc}$ & $20.56 \mathrm{a}$ \\
\hline & 24 spurs $\times 4$ buds & $22 \mathrm{~b}$ & $23 \mathrm{~b}$ & $15.75 \mathrm{e}$ & $16.8 \mathrm{de}$ & $462.5 \mathrm{ab}$ & $512.5 \mathrm{a}$ & $20.21 \mathrm{a}$ & $20.67 \mathrm{a}$ \\
\hline & 16 spurs $\times 6$ buds & $22.8 b$ & $24.3 b$ & $18 \mathrm{cde}$ & 19 cde & $487.5 \mathrm{a}$ & $522.5 \mathrm{a}$ & $18.23 \mathrm{abc}$ & $19.93 \mathrm{ab}$ \\
\hline
\end{tabular}

Values within each column followed by the same letter/s are not significantly different at $5 \%$ level

\section{Physical characteristics of berries}

Data presented in table (5) revealed that the highest values of berry weight, size, width and length were obtained when the vines were pruned at(48 buds/vine) 24 spurs/2 buds as compared with the other treatments in 2016 and 2017seasons followed by the vines were pruned at ( 48 buds/vine) 8 spur $\times 6$ buds as compared with the other treatments in 2016 and 2017seasons, respectively. While,vines were pruned at(96 buds/vine) 24 spurs with 4 buds gave the lowest berry weight, size, widthand lengthcompared with the other treatments in both seasons of study.

Regarding shoot berries percentage per cluster of in the same table revealed that pruning Early sweet grapevines (48 buds/vine) 12 spurs/4 buds decreased shoot berriespercentage per clusteras compared with(72 buds/vine)and (96 buds/vine) in 2016 and 2017seasons, respectively. While, vines pruned to (96 buds/vine) 48 spurs with 2 buds gave the highest shoot berriespercentage per cluster of compared with the other treatments in both seasons of study.

Table 5. Effect of different of buds load levels on 25 berries weight $(\mathrm{g})$, Size of berries (cm) ${ }^{3}$, Berry width, length $(\mathrm{cm})$ and shoot berries per cluster\%, of Early Sweet grapevines in 2016 and 2017 seasons

\begin{tabular}{|c|c|c|c|c|c|c|c|c|c|c|c|}
\hline \multicolumn{2}{|c|}{ Treatments } & \multicolumn{2}{|c|}{$\begin{array}{l}25 \text { berries } \\
\text { weight }(g)\end{array}$} & \multicolumn{2}{|c|}{$\begin{array}{l}\text { Size of } \\
\text { berries }(\mathrm{cm})^{3}\end{array}$} & \multicolumn{2}{|c|}{$\begin{array}{l}\text { Berry } \\
\text { width(mm) }\end{array}$} & \multicolumn{2}{|c|}{$\begin{array}{l}\text { Berry } \\
\text { length(mm) }\end{array}$} & \multicolumn{2}{|c|}{$\begin{array}{l}\text { shoot } \\
\text { berries per } \\
\text { cluster \% }\end{array}$} \\
\hline & & 2016 & 2017 & 2016 & 2017 & 2016 & 2017 & 2016 & 2017 & 2016 & 2017 \\
\hline \multirow{5}{*}{48} & 24 spurs $\times 2$ buds & $117.2 \mathrm{a}$ & 120.a & $115.4 \mathrm{a}$ & 118.a & $19.8 \mathrm{a}$ & $21 \mathrm{a}$ & $23.2 \mathrm{a}$ & $23.7 \mathrm{a}$ & $2.8 \mathrm{e}$ & $3.1 \mathrm{~d}$ \\
\hline & & $96 b c$ & 99.3 & 102.5 & 108.3 & 19 & 19.6 & 22.6 & 23.1 & 2.1 & 2.6 \\
\hline & 12 spurs $\times 4$ buds & & $\mathrm{bc}$ & bcd & $\mathrm{b}$ & $a b$ & $a b$ & $\mathrm{a}$ & $\mathrm{a}$ & $\mathrm{e}$ & $\mathrm{D}$ \\
\hline & & 101.3 & 105 & 105 & 108 & 19.5 & 20.3 & 22.4 & 22.9 & 3.7 & 4.1 \\
\hline & 8 spurs $\times 6$ buds & $\mathrm{b}$ & $\mathrm{b}$ & $\mathrm{bc}$ & $\mathrm{b}$ & $a b$ & $a b$ & $\mathrm{a}$ & $\mathrm{a}$ & cde & $\mathrm{Cd}$ \\
\hline \multirow{6}{*}{72} & 26 onum & 86.7 & 93.3 & 97.7 & 100.7 & 19.7 & 18.9 & 23 & 23.7 & 6.2 & 7.4 \\
\hline & 36 spurs $\times 2$ buds & Bcd & bcd & bcd & $\mathrm{b}$ & $a b$ & $a b c$ & $\mathrm{a}$ & $\mathrm{a}$ & bcde & $\mathrm{Bc}$ \\
\hline & & 96.8 & 103 & 99.5 & 102.3 & 17.7 & 18.4 & 19 & 20 & 9.4 & 10.1 \\
\hline & 18 spurs $\times 4$ buds & $\mathrm{Bc}$ & $\mathrm{b}$ & bcd & $\mathrm{b}$ & $\mathrm{bc}$ & $\mathrm{bc}$ & $\mathrm{bc}$ & bc & b & B \\
\hline & & 82.8 & 87.5 & 96.3 & 100 & 18.7 & 19.2 & 21.6 & 22.1 & 6.9 & 7.5 \\
\hline & 12 spurs $\times 6$ buds & $\mathrm{Cde}$ & cde & $\mathrm{cd}$ & $\mathrm{b}$ & $a b$ & $a b c$ & $\mathrm{a}$ & $a b$ & $\mathrm{bc}$ & $\mathrm{Bc}$ \\
\hline \multirow{6}{*}{96} & & $73.5 \mathrm{~d}$ & 81 & 95 & 100.3 & 18.4 & 18.9 & 21.4 & 22 & 19.1 & 19.7 \\
\hline & 48 spurs & ef & de & $\mathrm{d}$ & $\mathrm{b}$ & $a b$ & $a b c$ & $a$ & $a b$ & $\mathrm{a}$ & A \\
\hline & & 66.75 & 77.5 & 61.3 & 77.5 & 16.5 & 17.4 & 17.6 & 18.4 & 17.2 & 18.0 \\
\hline & $24 \operatorname{spurs} x$ & $\mathrm{f}$ & $\mathrm{e}$ & $\mathrm{f}$ & c & $\mathrm{cd}$ & $\mathrm{cd}$ & c & c & $\mathrm{a}$ & A \\
\hline & $1 \epsilon+2>$ & 70 & 75 & 75 & 80 & 15.9 & 16.2 & 18.1 & 18.7 & 16.4 & 17.4 \\
\hline & 16 & ef & $\mathrm{e}$ & $\mathrm{e}$ & $\mathrm{c}$ & $\mathrm{d}$ & $\mathrm{d}$ & $\mathrm{c}$ & c & $\mathrm{a}$ & A \\
\hline
\end{tabular}

Values within each column followed by the same letter/s are not significantly different at 5\% level 
Ali and MoumenKh. Mohamed, 2016 showed that the highest berry weight, size, width and length were recorded on the vines that pruned to leave 15 fruiting spurs $\mathrm{x}$ 4eyes and decreasing shoot berries per cluster percentage of Early Sweet grapevines. Also, Hussain and El-Dujaili, (1990),Abd El-Baki (2003) and Sabbatiniet al. (2015) mentioned that as number of nodes retained increased, berry weight of 'Niagara' grapevines increased

\section{Chemical characteristics}

Total soluble solids content $(\%)$, Acidity and TSS/acid ratio

Data presented in Table (6) indicated that non significantly difference between all treatments in both seasons on total soluble solids content (\%), Acidity and TSS/acid ratio of Early sweet
grapevinescultivar.Since, vines were pruned at (48 buds/vine) 12 spur $\times 4$ buds and (48 buds/vine) 24 spur $\times 2$ buds gave the highest total soluble solids content and decreased Aciditycompared with treatments (72 buds/vine)and (96 buds/vine) respectively in both seasons of study while treatment (96 buds/vine) 48 spurs $\times 2$ buds gave the lowest value oftotal soluble solids contentand increased Aciditycompared with the other treatments in 2016 and 2017seasons this study

This is agreement with those mentioned by Dhillon (2004), Almanza-Merchan et al. (2014) and Sabbatini et al. (2015) stated that long pruning type presented the highest values of TSS\%. Beside, Rizket al. (1994) and Abd El-Wahab (1997) recorded that total soluble solids of grape berries was not affected by treatments of bearing unit length. In this trend, Ansam (2002) and Cangi and Klc (2011) found that bud loading had no effect on total soluble solids in addition.

Table 6. Effect of different of buds loadlevels on TSS, Acidity\% and TSS/acid ratio of Early Sweet grapevines in 2016 and 2017 seasons

\begin{tabular}{|c|c|c|c|c|c|c|c|}
\hline \multicolumn{2}{|c|}{ Treatments } & \multicolumn{2}{|c|}{ TSS\% } & \multicolumn{2}{|c|}{ Acidity\% } & \multicolumn{2}{|c|}{ TSS/acid ratio } \\
\hline & & 2016 & 2017 & 2016 & 2017 & 2016 & 2017 \\
\hline \multirow{3}{*}{48} & 24 spurs $\times 2$ buds & $17.2 \mathrm{a}$ & $17.7 \mathrm{a}$ & $0.374 \mathrm{a}$ & $0.374 \mathrm{ab}$ & $45.9 \mathrm{a}$ & $45.7 \mathrm{a}$ \\
\hline & 12 spurs $\times 4$ buds & $17.3 \mathrm{a}$ & $17.7 \mathrm{a}$ & $0.363 b$ & $0.375 \mathrm{a}$ & $47.6 \mathrm{a}$ & $47.2 \mathrm{a}$ \\
\hline & 8 spurs $\times 6$ buds & $16.8 \mathrm{ab}$ & $17.3 \mathrm{ab}$ & $0.367 \mathrm{ab}$ & $0.375 \mathrm{a}$ & $45.4 \mathrm{ab}$ & $46.1 \mathrm{a}$ \\
\hline \multirow{3}{*}{72} & 36 spurs $\times 2$ buds & $16 a b$ & $16.5 \mathrm{ab}$ & $0.373 \mathrm{ab}$ & $0.387 \mathrm{a}$ & $42.8 \mathrm{ab}$ & $42.6 \mathrm{ab}$ \\
\hline & 18 spurs $\times 4$ buds & $16.4 \mathrm{ab}$ & $16.8 \mathrm{ab}$ & $0.365 \mathrm{ab}$ & $0.375 \mathrm{a}$ & $44.9 \mathrm{ab}$ & $44.8 \mathrm{ab}$ \\
\hline & 12 spurs $\times 6$ buds & $16.3 \mathrm{ab}$ & $16.8 \mathrm{ab}$ & $0.367 \mathrm{ab}$ & $0.378 \mathrm{a}$ & $44.4 \mathrm{ab}$ & $44.4 \mathrm{ab}$ \\
\hline \multirow{3}{*}{96} & 48 spurs $\times 2$ buds & $16.5 \mathrm{ab}$ & $16.0 \mathrm{ab}$ & $0.387 \mathrm{a}$ & $0.390 \mathrm{a}$ & $42.6 .1 \mathrm{ab}$ & $41.0 \mathrm{~b}$ \\
\hline & 24 spurs $\times 4$ buds & $16.8 \mathrm{ab}$ & $16.1 \mathrm{ab}$ & $0.373 \mathrm{ab}$ & $0.383 \mathrm{a}$ & $45.0 \mathrm{ab}$ & $42.0 \mathrm{ab}$ \\
\hline & 16 spurs $\times 6$ buds & $16.8 \mathrm{ab}$ & $16.0 \mathrm{ab}$ & $0.375 \mathrm{a}$ & $0.365 \mathrm{ab}$ & $44.0 \mathrm{ab}$ & $43.8 \mathrm{ab}$ \\
\hline
\end{tabular}

Values within each column followed by the same letter/s are not significantly different at 5\% level

\section{At dormant seasons}

\section{Carbohydrates, Wood ripening and Weight of pruning/vine}

The data presented in Table (7) revealed vines were prunedat(48 buds/vine) 24 spurs/ 2 buds gave the highest Wood ripening and Weight of pruning per vinecompared with (72 buds/vine)and (96 buds/vine) respectively in both seasons of study. On the other hand ,the lowest value ofwood ripening and weight of pruning per vine was obtained whenvines were pruning at ( 72 buds/vine) 12 spurs $\times 6$ buds in both seasons of the study while different levels of buds load gave a non significantly differences in carbohydrates in canes except pruning ( 72 buds/vine) 12 spur $\times 6$ buds gave the lowest valuecompared with other treatments of study. Our results in this connection agree with those obtained by Omar \& Abdel-kawi (2000) who reported that increasing leaves lead to heavy canopy with increase in active photosynthesis and stored carbohydrates in the new canes. Similar results were obtained by El-Bazet al., (2002) on Crimson seedless grapevines Genaidy (2015) increasing the buds on the vineyard led to a weight loss of wood pruning and mature wood.

\section{Conclusion}

From the previous results, it can be recommended that pruning Early Sweet grapevine at (48 bud/vine) namely 24,12 and 8 fruiting spurs adopted to 2,4and 6 buds/spur gave highest values of bud behavior, physical characteristics and vegetative growth .Also increased wood ripening, weight of pruning and total carbohydrate in canes However, the bud load of (96 bud/vine) 24 spurs $\times 4$ buds gave the highest with yield per vine in both season in both seasons 
Table 7. Effect of different of buds load levels on carbohydrates, Wood ripening and Weight of pruning/vine(g) of Early sweet grapevines in 2016 and 2017 seasons

\begin{tabular}{|c|c|c|c|c|c|c|c|}
\hline \multicolumn{2}{|c|}{ Treatments } & \multicolumn{2}{|c|}{ carbohydrates $(\%)$} & \multicolumn{2}{|c|}{ Wood ripening } & \multicolumn{2}{|c|}{$\begin{array}{c}\text { Weight of } \\
\text { pruning/vine(g) }\end{array}$} \\
\hline & & 2016 & 2017 & 2016 & 2017 & 2016 & 2017 \\
\hline \multirow{3}{*}{48} & 24 spurs $\times 2$ buds & $35.56 \quad \mathrm{a}$ & $35.60 \mathrm{a}$ & $0.962 \mathrm{a}$ & $0.969 \mathrm{a}$ & $3.77 \mathrm{a}$ & $4.13 a$ \\
\hline & 12 spurs $\times 4$ buds & $31.10 \mathrm{ab}$ & $35.07 \mathrm{a}$ & $0.903 b$ & $0.912 b$ & $2.83 \mathrm{~b}$ & $3.07 \mathrm{~b}$ \\
\hline & 8 spurs $\times 6$ buds & $31.94 \mathrm{ab}$ & $34.71 \mathrm{a}$ & $0.813 \mathrm{c}$ & $0.826 \mathrm{c}$ & $2.70 \mathrm{~b}$ & $2.91 \mathrm{~b}$ \\
\hline \multirow{3}{*}{72} & 36 spurs $\times 2$ buds & $34.91 \mathrm{a}$ & $31.16 \mathrm{ab}$ & $0.957 \mathrm{a}$ & $0.966 \mathrm{a}$ & $3.96 \mathrm{a}$ & $4.04 \mathrm{a}$ \\
\hline & 18 spurs $\times 4$ buds & $32.70 \mathrm{a}$ & $27.86 \quad \mathrm{~b}$ & $0.902 \mathrm{~b}$ & $0.910 \mathrm{~b}$ & $2.90 \mathrm{~b}$ & $3.125 b$ \\
\hline & 12 spurs $\times 6$ buds & $31.94 \mathrm{ab}$ & $32.02 \mathrm{ab}$ & $0.755 d$ & $0.770 \mathrm{~d}$ & $2.60 \mathrm{~b}$ & $2.85 \mathrm{~b}$ \\
\hline \multirow{3}{*}{96} & 48 spurs $\times 2$ buds & $34.96 \mathrm{a}$ & $34.98 \mathrm{a}$ & $0.947 \mathrm{ab}$ & $0.936 \mathrm{ab}$ & $3.75 a$ & $3.94 \mathrm{a}$ \\
\hline & 24 spurs $\times 4$ buds & $34.65 \mathrm{a}$ & $32.745 \mathrm{a}$ & $0.903 \mathrm{c}$ & $0.911 \mathrm{~b}$ & $3.06 \mathrm{~b}$ & $3.28 b$ \\
\hline & 16 spurs $\times 6$ buds & $27.7 \quad b$ & 33.88 & $0.770 \mathrm{~d}$ & $0.779 \mathrm{~d}$ & $2.73 b$ & $3.025 b$ \\
\hline
\end{tabular}

Values within each column followed by the same letter/s are not significantly different at $5 \%$ level

\section{References}

A.O.A.C.(2000). Association of Official Agricultural Chemists. Official Methods of Analysis. 4th ed.pp. 495-510. Benjamin Franklin Station, Washington. D.C., U.S.A.

Abd El-Baki, M.S.A. ( 2003). Effect of summer pruning and thinning on growth and fruiting of King Ruby grapes. M.Sc. Thesis., Fac. of Agric., Cairo Univ., Cairo, Egypt

Abd El-Wahab, M. A. (1997).Effect of cane length on bud behaviour, growth and production of "king Ruby" grapevines.M. Sc. Thesis, Cairo University, Egypt.

Abdel-Fattah S.E; Marwad, I. A; and Isis AbdelshahiedRizk (1993). Effect of bud load and spur length on Roumi Red grapevine I-Weight of pruning and chemical compostion of 1 year - old wood. Zagazig.J. Agric.. Res Vol 2.0 No. (6) pp1889 -1899

Abdel-Mohsen, M.A. (2013): Application of various pruning treatments for improving productivity and fruit quality of crimson seedless grapevine. World Journal of Agricultural Sciences 9 (5): 377-382

Almanza-Merchan, P.J., G.R. Fischer and G.E. Cely( 2014). The importance of pruning to the quality of wine grape fruits (Vitisvinifera L.) cultivated under high-altitude tropical conditions. AgronomiaColombiana, 32(3): 341-348.

Aly, M.S.M.( 2001) Effect of bud load and some growth regulators on growth, yield and fruit quality of King's Ruby grapevine cultivar. Ph. D. Agric. Sci., Ain Shams University, Cairo, Egypt

Ali, A.H.; M.Kh. Uwakiem and H.M.M. Sayed(2016)Effect of Vine Load and Spraying Citric Acid on Fruiting of Superior Grapevines Grown Under Minia Region Conditions- Egypt Assiut J. Agric. Sci., (47) No. (6-2) 2016 (484-503)

Ali H. Ali and Moumen A. Kh. Mohamed( 2016) Effect of Fruiting Spur Length and Spraying Seaweed Extract on Yield and Berries Quality of Early Sweet Grapevines Assiut J. Agric. Sci., (47) No. (6-2) 2016 (504-517) ISSN: 1110-0486
Ansam, S.A. El.,(2002). Effect of cane length on bud behaviour, growth and productivity of "Superior" grapevines. M.Sc. Thesis, Fac. of Agric., Cairo Univ., Egypt.

Awad, N.A.E. (2003): Studies on pruning severity of Thompson seedless grapes. M. Sc. Thesis Fac. of Agric. Mansoura Univ. Egypt

Bessis, R. (1960). Sur Differents Models Expression Quantitative Delafertilité chez la vigneAca p.p. $828-882$.

Cangi, R. and D. Klc, (2011) Effects of bud loading levels and nitrogen doses on yield, physical and chemical properties of brined grape-leaves. African Journal of Biotechnology, 10(57): 1219512201.

Celik, H., Y.S. Agaoglu, Y. Fidan, B. Marasali and C. Soylemezoglu, (1998). General Viticulture. Professional Books Series, Ankara, 1: 1-253.

Cottenie, A.; M. Verloo; L. Kiekens; G. Relgho and W. Camerlynuck (1982). Chemical analysis of plant and soil. Lab. of analytical and Agrochemistry State Univ. Gent, Belgium

Dhillon, W.S. (2004).Standardization of pruning intensity in grape cv. Perlette. Haryana Journal of Horticultural Sciences, 33(3/4): 172-174.Cangi, R. and D. Klc, 2011. Effects of bud loading levels and nitrogen doses on yield, physical and chemical properties of brined grape-leaves. African Journal of Biotechnology, 10(57): 12195 -12201.

Duncan, B. D. (1955). Multiple test range and multiple F tests. Biometries. 11-142.

El- Ashram, M.A. (1993): Modern Approaches of Cultivation and Production of Grapevines. Dar ElFekr, El- Arabie, pp. 275-276.

EL-Baz, EI. EI. T.; A.M. Mansour; EI.F.EI-Dengawy and B.N. Samra (2002) Influence of pruning severity on bud behavior, yield, ,berry quality and some biochemical contents of the canes of "Crimson seedless" Grapes. Egypt.j.Hort.29(1) pp.39-60.

Fawzi, F., Bondok, A.Z. and Ghobrial, G. F. (1984). Effect of cane length on bud behaviour and wood ripening of Thompson seedless grape variety, 
Annals Agric., Sci., Ain Shams Univ., Cairo 29 (1) 465-474.

Fawzi, F., F.H. Laila, M.F.M. Shahin, M.A. Merwad and E.A.E. Genaidy( 2015). Effect of vine bud load on bud behavior, yield, fruit quality and wood ripening of superior grape cultivar. International Journal of Agricultural Technology, 11(5): 12751284.

Genaidy,E.(2015).Effect of vine bud load on bud behavior,yield, fruit quality And wood ripening of superior grape cultivar.J of Agr.Tech,1275-1284

Herbert, D.;P.J.Phipps and R.F.Strange(1971). Determination of total carbohydrates Methods in Microbian;5(B):209-244.

Hussain, M.M. and J.A.H. El-Dujaili(1990). Effect of bud level and training system on yield and quality of Dies El-Anz grape cultivar (Vitisvinifera. L.). Hort. Abst., 62: 6472.

Jarad, A. (2004): Effect of fruit canes and eyes vine load on the productivity of a local grape variety under the conditions of Deir El- Zor city. Bull Fac. Agric. Cairo Univ, 55: 603-608

Kamel, M.K. (2002): Physiological studies on pruning and fertilization of Flame seedless grapevines. ( $V$. vinifera L.). Ph. D. Thesis. Fac. Of Agric. Minia Univ. Egypt

Khamis , M. A.; A.A.R.Atawia; H.E.M.El-Badawy and A.A.M.Abd EL-Samea (2017) Effect of buds load on growth, yield and fruit quality of Superior Grapevines. Middle East. J.ofAgric .Res ISSN2077-4605.Vol:061 Issue:01 . J- Mar pag: 152-160

Mackinny, G. (1941). Absorption of light by chlorophyll soluation. J. Bio. Chem., 140: 315322.

Marwad, I. A.; Rizk, N. A and Ibrahim, A. H(1993). Effect of cane length on bud behaviour, Yield, bunch characteristics and wood maturity of Thompson seedless grapevines Egypt. J. Appl. Sci., 8 (12) pp 47-60.

Morris, J. R. and D. L. Cawthan (1980). Yield and quality response of "Concord grapes to training systems and pruning severity in Arkansas, J. Amer. Soc. Hort. Sci., 105 (3): 307-10. (Hort. Abst. 51: 233).

Nejatian, M.A. (2003): Effects of bud number and cane length on bud fertility and some characteristics of grapevine cv. Bidanehsefid, 19(4): 457-467.

Omar, A.H and Abdel- kawi, A. (2000). Optimal bud load for Thompson seedless grapevines. J. Agric Sci. Mansoura Univ. 25 (9), pp5769-5777.
Ranspise, S. A.; Patil, B. T.; More, T. A.; Birade, R. M.; Ghure, T. K., (2003): Effect of sub-cane pruning on fruitfulness and yield of grape cV Thompson seedless. Journal of Maharashtra Agricultural Universities.27 3: 258-259

Rizk, I. A. (1996). Effect of cane length on bud behaviour and bunch characteristics in "Thompson seedless" cultivar. Egypt. J. Appl. Sci., 11 (7): 220-34.

Rizk, N. A.; I. A. Rizk and V. H. Girgis (1994). Effect of cane length on bud behaviour, wood ripening and bunch characteristics in "Thompson seedless" grapevines. Egypt. J. Appl. Sci., 9 (5): 74-89.

Rubio, J.A., Albuquerque M. V., peixy, J.L and yuste . J. (2002). la mejora varietal de la vid, susconsescuencias y beneficios. Vida Rural, pp 149: pp 62-66

Sabbatini, P., K. Wierba, L. Clearwater and G.S. Howell( 2015). Impact of training system and pruningseverity on yield, fruit composition, and vegetative growth of 'Niagara' grapevines in Michigan International Journal of Fruit Science, 15(3): 237-250.

Senthilkumar.S,Vijayakumar.R.M.,Soorianathasunda ram.K.andDurgadevi.D.(2015)Effect of pruning severity on vegetative, phgsiological, yield And quality attributes in grape (vitis vinifera L.) :AReview.Curr.Agi Res.J.Vol.3(1),42-54.

Snedecor, G.A. and W.G.Cochran(1990).Statistical Methods. $6^{\text {th }}$ ed the lowa state. Univ.press.Iowa U.S.A.

Tamura, F.; Muraya, K. and Fujji, Y. (2002): Effects of short cane pruning in summer and long cane pruning in winter on growth and yield of the grapevine "Muscat" of Alexandria' in forcing culture condition. Hort. Res. (Japan), 1(4): 269274. (Hort. Abst., 73(5): 4269).

Tourky, M.N., El-Shahat, S.S. and Rizk, M. H. (1995).Effect of Dormex on fruit set, quality and storage life of Thompson seedless grapes (Banati grapes) J. Agric. Sci., Mansoura Univ., 20(12): 5139-5151.

Velu, V. (2001)Studies on bud load and certain crop thinning practices on vigour, yield and quality of grapes (Vitisvinifera L.) cv. Muscat. M.Sc.,

Weaver, R.J.( 1976). Grape Growing. WileyInterscience Publication, John Wiley \& Davis,

New York, London, Sydney, Tronto pp. 160175. 


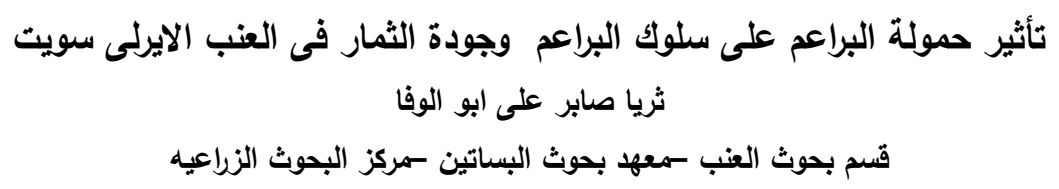

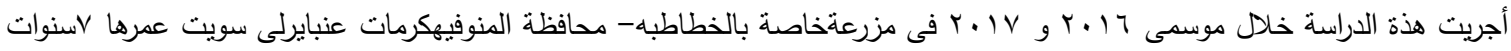
ومنزرعة فى تربة رمليه تروى بالتنقيط وعلى مسافة زراعة بXY م ومرباه بطريقة الكردون الرباعى باستخدام نظام تدعيم البارون سيستم . وقد استهدف هذا البحث دراسة تأثير حمولة البراعم على سلوك العيون وجودة الثمار فى العنب الايرلى سويت.

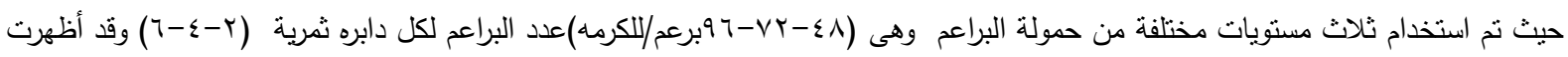

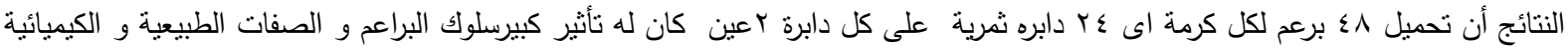

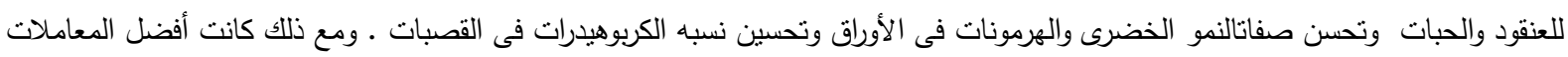

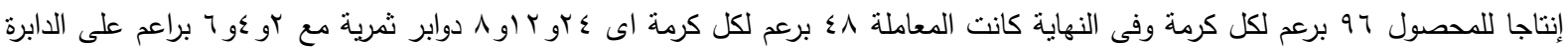
الثرية على التوالى تحت الدراسة افضل المعاملات 